\title{
The Influence of Perch Height Selection on Vocalization of Pied Triller, Lalage nigra (Aves: Campephagidae) in Suburban Landscapes, Sarawak
}

\author{
AMERA NATASHA MAH MUHAMMAD ADAM MAH ${ }^{1} \&$ MOHAMAD FIZL SIDQ RAMJ*22 \\ ${ }^{1}$ Faculty of Forestry and Environment, Universiti Putra Malaysia, 43400 UPM Serdang, Selangor, Malaysia; \\ ${ }^{2}$ Faculty of Resource Science and Technology, Universiti Malaysia Sarawak, 94300 Kota Samarahan, Sarawak, \\ Malaysia \\ *Corresponding author: rmfizl@unimas.my \\ Received: 30 October 2020 Accepted: 11 December $2020 \quad$ Published: 31 December 2020
}

\begin{abstract}
Understanding how birds utilised songs and calls to communicate among conspecifics is crucial for their survival, yet it remains an understudied area in bird ecology. We studied the influence of perch height selection on the vocalisation of Pied Triller, a common garden bird, in two suburban landscapes namely Pustaka Negeri Sarawak Recreational Park, Kuching and Universiti Malaysia Sarawak campus, Kota Samarahan from October 2018 to February 2019. Using a Marantz recorder connected to a parabolic reflector, we recorded calls and songs during morning (0630-1030 hr) and late afternoon (1600-1830 hr). Perch object, tree species, roost substrate and perch height from the ground were identified and measured. Clear and good quality spectrograms were used directly to describe song and call types. Photos and video recordings were analysed to describe perch behaviour. The vocal output representatives were then matched to the corresponding behaviour displayed. Our results revealed that Pied Trillers emit four different vocal outputs namely (i) song type, (ii) call type A, (iii) call type B and (iv) call type C. A total of nine behaviours were observed, of which the perch-hop behaviour was observed the most from both male and female Pied Trillers (33.71\%), followed by perching $(29.21 \%)$, foraging $(20.22 \%)$, preening $(7.78 \%)$, defecating $(2.25 \%)$, eating $(2.25 \%)$, roosting $(2.25 \%)$, bill wipe $(1.12 \%)$ and flight $(1.12 \%)$. They prefer to roost on high perch to emit calls compared to songs. This probably suggest that Pied Triller prioritised vocal transmission and signalling to avoid being masked by surrounding anthropogenic noises and to avoid being conspicuous to potential predators. The most frequently visited perch object was the Weeping fig tree, Ficus benjamina.
\end{abstract}

Keywords: Call, perch height, Pied Triller, song, suburban landscapes

Copyright: This is an open access article distributed under the terms of the CC-BY-NC-SA (Creative Commons Attribution-NonCommercial-ShareAlike 4.0 International License) which permits unrestricted use, distribution, and reproduction in any medium, for non-commercial purposes, provided the original work of the author(s) is properly cited.

\section{INTRODUCTION}

Pied Triller, Lalage nigra (Family: Campephagidae) is a common resident in the lowlands of Borneo and a familiar garden bird (Smythies, 1999). This cuckoo-shrike is also often seen foraging for insects in foliage of small trees of open habitats, urban gardens, coastal Casuarinas, and mangroves (MacKinnon \& Phillipps, 1993; Phillipps \& Phillipps, 2014). They are sexually dimorphic with males having black upperparts with white wing bar and white edges to wing converts and outer tail feathers, broad white eyebrow with black eye-stripe and grey rump (MacKinnon \& Phillipps, 1993). Comparatively, females are similar but brown instead of black and the breast are finely barred with black.

There are two types of bird vocalisations which are calls and songs (Welty \& Baptista, 1988). Calls tend to be shorter, simpler, and produced by both sexes throughout the year (Catchpole \& Slater, 2008). They are also less spontaneous and often related to specific function such as flight, threat, and alarm. A song on the other hand is more complex than a call and occurs spontaneously (Welty \& Baptista, 1988). Songs also constitute a group of notes separated from another group of notes by a pause longer than the pauses between the notes themselves (Welty \& Baptista, 1988). When illustrating a song, sonograph is used to analyse, measure, classify and recognise the different sounds produced by the birds (Catchpole $\&$ Slater, 2008). Therefore, discrimination between different species, population, individuals, song type within individuals and renditions of the same song type from an individual bird was possible (Catchpole \& Slater, 2008).

A Pied Triller's call can vary from a distinctive 
double syllable chwee whuk (Phillipps \& Phillipps, 2014) to a double croak chook-chook or a rolling, descending tre-tre-tre-tre, more musical than the rich, vigorous, metallic whistle of a Whiteshouldered Triller (MacKinnon \& Phillipps, 1993). Smythies (1999) described the call as double note similar to the croak of a frog, while Vowles and Vowles (1997) described the call as a harsh grating chat.

There has been a dearth of studies that focused on ecological roles and behavioural adaptation of bird vocalisation. Such is shown by the limited vocal recordings available for Pied Triller from Borneo in online bird call archives such as XenoCanto Foundation and Macaulay Library at the Cornell Lab of Ornithology. Only two song recordings were available in Xeno-Canto Foundation (2013) recorded from Mantanani Resort, Pulau Mantanani Besar, Sabah and another song recorded from a paddy field in Penampang, Sabah. Previous studies reported that city birds in general tend to choose higher perch height due to anthropogenic noise in order to efficiently transmit sexual and territorial vocal displays at the same time minimising risk of predation due to avian and mammalian predators (Møller, 2011). The primary objective of this study is to determine the influence of perch height selection on vocalisation of Pied Triller in suburban landscapes. This study hypothesised that perch height selection could influence the vocalisation of Pied Triller. A higher perch height will be chosen to emit calls over songs based on the six vocal output parameters. Urban noise will influence a higher perch height preference by the bird.

\section{MATERIALS AND METHODS}

\section{Study Site}

The study was conducted in two suburban landscapes. The first study site was in Pustaka Negeri Sarawak $\left(\mathrm{N} 1.58^{\circ}, \mathrm{E} 110.35^{\circ}\right.$, E: $12 \mathrm{~m}$ asl) (Figure 1). This public library is located adjacent to the Sarawak State Mosque and the Sarawak Golf Club in Petra Jaya, Kuching Division. The 37.23 ha recreational park consists mixture of landscape mainly a lake, grassland, wetlands, open and dense forest and some formal gardens (Pharo et al., 2015). The mixture of vegetation in the recreational park hosts about 4741 ornamental shrubs and flowering plants, 878 local tree species, 336 fruit trees, 275 palm species and 50 different herbs (Pharo et al., 2015).

The second study site was conducted in the West Campus of Universiti Malaysia Sarawak (UNIMAS) (N1.46 ${ }^{\circ}$ E110.43 ${ }^{\circ}$, E: $17 \mathrm{~m}$ asl) in Kota Samarahan Division (Figure 1). The campus is approximately 2000 ha in size, surrounded by secondary mix peat swamp forests with a thin strip of mangrove vegetation along the river (Voon et al., 2014). The campus has diverse types of vegetation consisting of mangrove plants (such as Avicennia spp., Sonneratia spp., Nypa fructicans, and Rhizophora spp.), ornamental urban trees, Macarthur palms, Fig trees, and Acacias. The five most common tree species planted in UNIMAS are Fern tree, Filicium decipiens, Indonesian bay leaf tree, Syzygium polyantha, Florida royal palm, Roystonea regia, wild Cinnamon tree, Cinnamomum iners, and Spanish cherry tree,

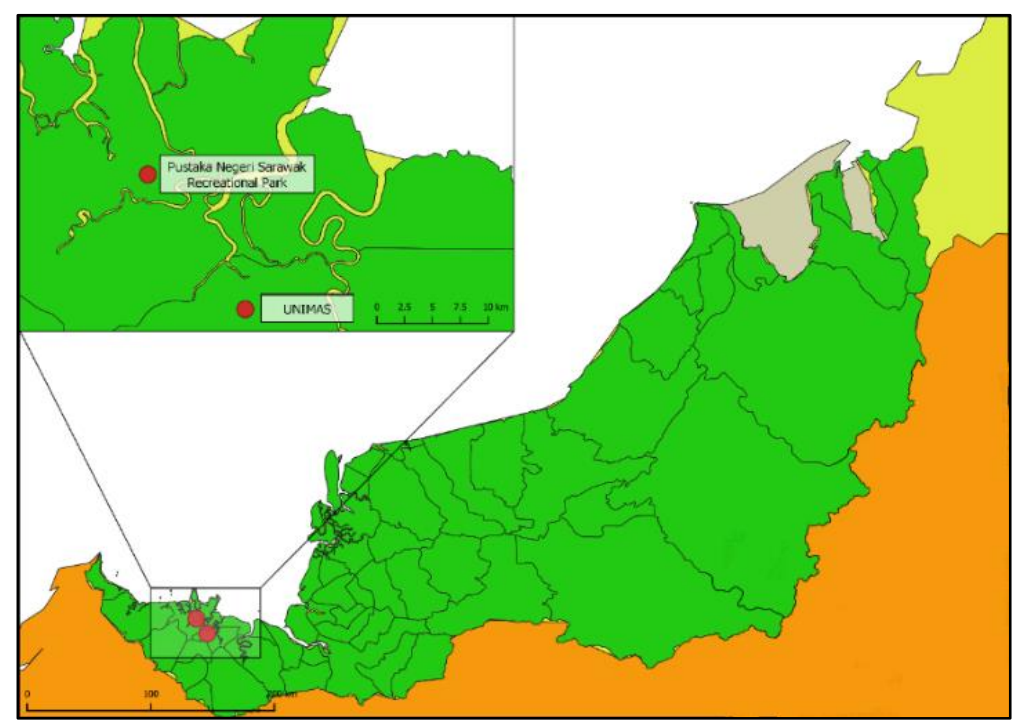

Figure 1. Map showing location of sampling sites in Kuching and Kota Samarahan (Modified after QGIS 3.6.2) 
Mimusops elengi (Zainudin et al., 2012).

\section{Sampling Method}

Active sampling method was conducted in this study by walking a predetermined $100 \mathrm{~m}$ transect lines while simultaneously recording bird calls and songs using (i) a digital recorder (Barker \& Mennill, 2009) (Marantz PMD-671, sample frequency $44.1 \mathrm{kHz}$, resolution $16 \mathrm{bit}$ ) that was connected to (ii) a Senheisser MKH 20 P48 omnidirectional microphone, (iii) a Sony Dynamics Stereo headphone MDR-7506 and (iv) a parabolic reflector. A laser rangefinder (Nikon Forestry Pro) was used to measure the height (m) of the bird perch from the ground. Four assumptions were made when recording includes (i) all individuals along the route were detected, (ii) birds do not move before detection, (iii) distances were measured accurately, (iv) individual birds were counted only once (Bibby et al., 1992).

Audio recordings were carried out two to three times a week from October 2018 to February 2019. Bird calls and songs were recorded in the morning (0630 to $1030 \mathrm{hr}$ ) and late afternoon (1600-1830 hr). Individuals seen perching were photographed and captured in video to record roosting and call behaviour using a digital compact camera (Nikon Coolpix P900). For each observation, the perch height of the singing individual and the height of the tree was also measured (Krams, 2001). The sex of the individual, the presence of other individual, and the description of perch object were also recorded. Environment parameters that were recorded include temperature $\left({ }^{\circ} \mathrm{C}\right)$, humidity $(\%)$ and light intensity (Lux) of surrounding by using an Extech 45170CM 5-in-1 Environmental meter while cloud cover (\%) was recorded using an AccuWeather Application.

\section{Data Analysis}

To screen new vocal outputs for background noise, Audacity (version 2.1.2) was used to filter about 15 $\mathrm{dB}$ of background noise before visualising the spectrogram for each vocal output using Sound Ruler Acoustic Analysis (version 0.9.6.0). The good quality spectrograms were used directly by analysing the six vocal parameters including (i) dominant frequency, $\mathrm{kHz}$, (ii) minimum frequency, $\mathrm{kHz}$, (iii) maximum frequency, $\mathrm{kHz}$, (iv) duration of vocal, s, (v) relative amplitude, $\mathrm{dB}$ and the (vi) number of syllables of the vocal output, $n$.

Photos and video recordings of the perch observations were determined and analysed to describe the perch behaviour displayed. The vocal output representatives were then matched to the corresponding behaviour displayed. A multivariate linear regression in PAST software (version 3.14) (Hammer et al., 2001) was used to calculate the significant difference between perch height selection by the birds towards the six song output parameters. A vocal ethogram of the vocal bird was constructed based on Stanton (2016).

\section{RESULTS}

A total of 89 perch height observations were recorded consisting of 70 observations of male Pied Trillers (78.65\%), 16 females (17.98\%) and three male and female observed together (3.37\%). From this, 59 observations included songs and calls $(66.29 \%)$ while 30 observations were without songs and calls (33.71\%). Table 1 shows the total number of perch height observations.

\section{Vocal and Behavioural Analysis}

From the total observation, nine behaviours were

Table 1. Total number of perch height observations

\begin{tabular}{|c|c|c|c|c|}
\hline \multirow[b]{3}{*}{ Individual } & \multicolumn{4}{|c|}{ Number of perch height observations } \\
\hline & \multicolumn{2}{|c|}{ Include songs and calls } & \multicolumn{2}{|c|}{ Excluding songs and calls } \\
\hline & $\begin{array}{l}\text { Number of perch } \\
\text { height (n) }\end{array}$ & Percentage $(\%)$ & $\begin{array}{l}\text { Number of perch } \\
\text { height (n) }\end{array}$ & Percentage $(\%)$ \\
\hline Male & 50 & 56.18 & 20 & 22.47 \\
\hline Female & 6 & 6.74 & 10 & 11.24 \\
\hline Male and Female & 3 & 3.37 & 0 & 0 \\
\hline Total observations & 59 & 66.29 & 30 & 33.71 \\
\hline
\end{tabular}


observed during the study. Perch-hop was the most observed behaviour from both male and female Pied Trillers $(33.71 \%)$, followed by perching $(29.21 \%)$, foraging $(20.22 \%)$, preening $(7.78 \%)$, defecating $(2.25 \%)$, eating $(2.25 \%)$, roosting $(2.25 \%)$, bill wipe $(1.12 \%)$ and flight $(1.12 \%)$. Figure 2 shows the percentage of the behaviour displayed by both sexes of the species.

Perch-hop - The bird hops actively from one branch to another with frequent short flights. They often pause in between to sing and call.

Perching - This behaviour is described when the bird is seen resting on a natural or artificial perch while looking around with its tarsus and toes firmly standing and gripping on the perch object. They occasionally emit songs and calls from a perch.

Foraging - This behaviour appears almost similar to that of a perch hop but the bird hops slower from one branch to another with less frequent short flights. Pied Triller typically spend more time gleaning the branches and leaves for insects in between hops or flights.

Preening - This behaviour is described as the bird naturally cleans and rearranged its feathers using its bill. They frequently sing in between preening.

Defecating - The bird expelled faeces through the anus from a perch. The bird normally sings after defecating.

Eating - This behaviour involves swallowing of food and intermittent movement of oesophagus. It does not accompany with songs and calls emitted by the bird.

Roosting - This behaviour describes the bird resting in a stationary state with its legs bend and less actively looking around. They do not emit songs and calls during a roost.

Bill wipe - This behaviour is described as the bird cleans its bill by wiping the sides on a perch. It does not accompany with songs and calls.

Flight - The bird takes off from a perch and flap its wings in irregular intervals. The bird has been seen singing during take-offs.

Four types of vocalisations were identified, consisting of song type, call type A, call type B and call type C. Figure 3 shows the spectrograms of all four vocalisation types with their respective description as follows:

Song type - This song type consists of a two note nasal tones varying from a descending tre-tre-tretre to a constant tre-tre-tre-tre. It can vary from seven to 24 syllables between 1.13 to $3.52 \mathrm{~s}$. Perchhop was the most observed behaviour that was displayed while emitting this song type.

Call type A - This call type also consists of a two note nasal tones which gives a pee-chit sound. It was emitted with two or four syllables between 3.6 to $9.6 \mathrm{~s}$. The most observed behaviour that was displayed while emitting this call type was perching.

Call type $B$ - This call type varies from a chit-cheedit-tre-tre-tre, chit-chee-dit-chit, and chit-chee-dit nasal tone sounds with duration between 0.52 to $2.6 \mathrm{~s}$. The observed behaviours displayed while emitting this call type were perching and perchhopping.

Call type $C$ - This call type is similar to song type but a syllable was only emitted giving a tre sound. It also consists of two note nasal tones sound with duration of $0.07 \mathrm{~s}$. Perching behaviour was observed while emitting this call type.

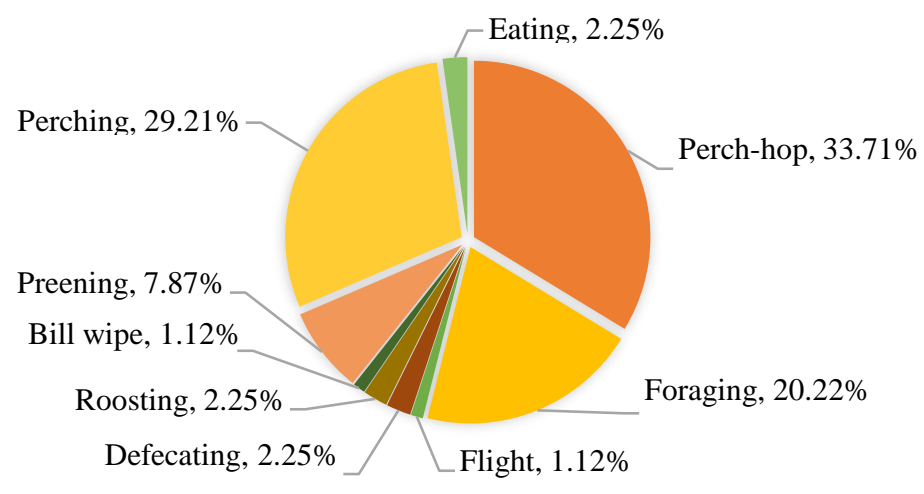

Figure 2. Pie chart showing the percentage of the behaviour displayed by both sexes of Pied Triller 

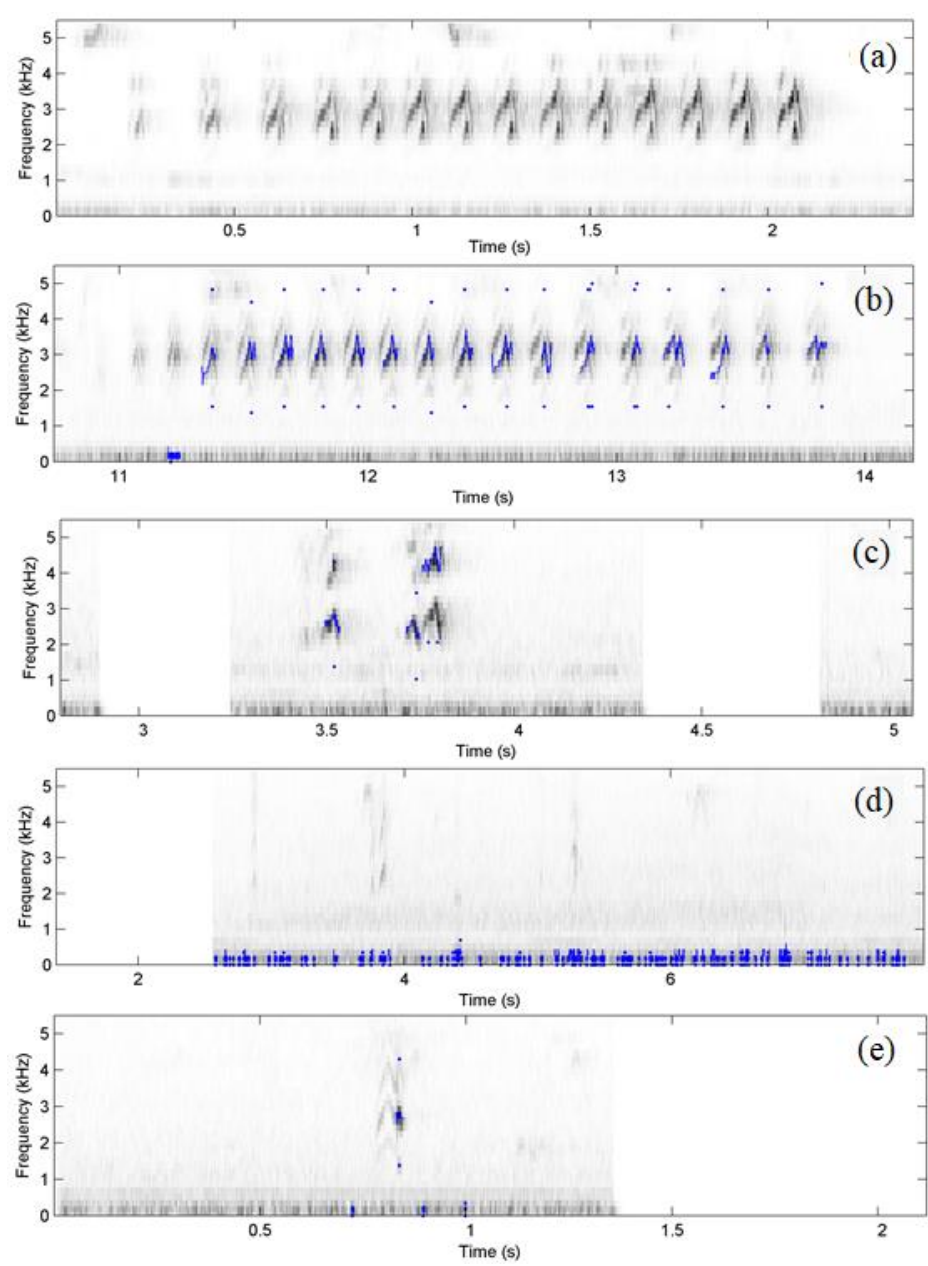

Figure 3. Spectrograms of song and call types of Pied Triller depicting (a) Song type - a descending 14 syllables, (b) Song type - 19 repeated syllables, (c) Call type A - a four syllables structure, (d) Call type B - varying nasal tone sounds with brief duration and (e) Call type $\mathrm{C}$ - a tre sound with two note nasal tones sound

\section{Perch Height and Perch Object Description}

A total of 87 perch height observations were recorded on tree structures $(97.75 \%)$ while two observations were on public parking signage $(2.25 \%)$ (Figure 4). Eight different tree species were identified including five ornamental trees and three timber trees (Table 2). Out of the five ornamental trees, four were fruiting trees while the other was a leguminous tree. The three timber trees consist of a fruiting tree and two leguminous tree. Public parking signage was least preferred as perching object by the bird.

Table 2. Percentage of perch tree in both sites

\begin{tabular}{llclc}
\hline & Ornamental tree & Percentage $(\%)$ & Timber tree & Percentage (\%) \\
\hline Fruiting & $\begin{array}{l}\text { Fern tree } \\
\text { (Filicium decipiens) }\end{array}$ & 2.25 & $\begin{array}{l}\text { Cheese tree } \\
\text { (Glochidion sp.) }\end{array}$ & 3.37 \\
$\begin{array}{l}\text { Weeping fig tree } \\
\text { (Ficus benjamina) }\end{array}$ & 29.21 & & \\
$\begin{array}{l}\text { Weeping paperbark tree } \\
\text { (Melaleuca leucadendra) }\end{array}$ & 1.12 & & \\
Blackboard tree & 23.6 & & 3.37 \\
(Alstonia scholaris) & 16.85 & $\begin{array}{l}\text { Moluccan albizia tree } \\
\text { (Albizia falcafacia) }\end{array}$ & 17.98 \\
& $\begin{array}{l}\text { Racacia tree } \\
\text { (Acacia sp.) }\end{array}$ & \\
\hline
\end{tabular}




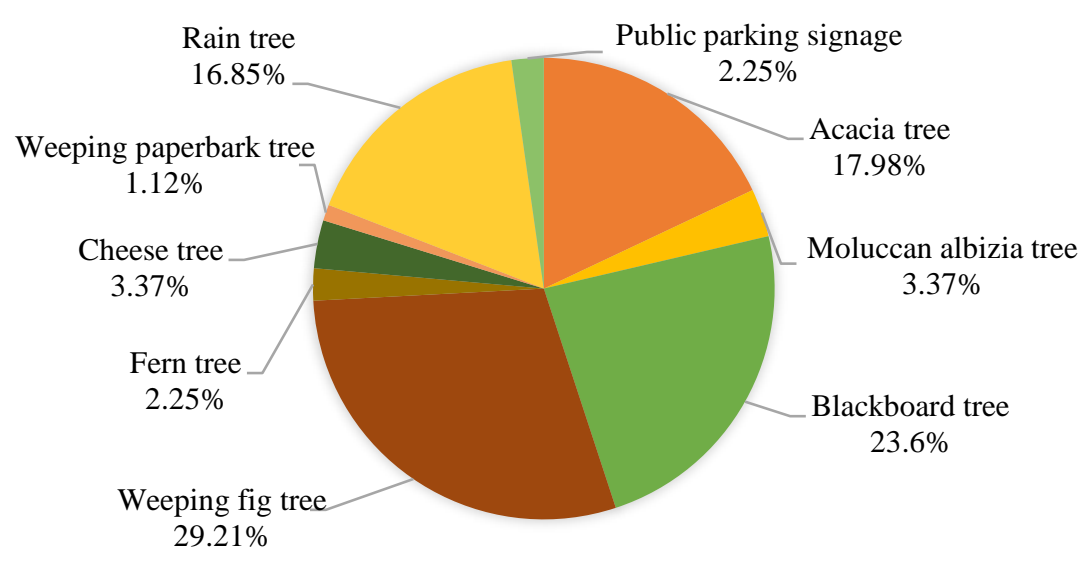

Figure 4. Pie chart showing the percentage of the perch objects

The highest tree perch height was at $21.6 \mathrm{~m}$ on a Weeping paperbark tree, Melaleuca leucadendra. This is followed by Cheese tree, Glochidion sp. $(8.13 \mathrm{~m})$, Acacia tree, Acacia sp. $(7.56 \mathrm{~m})$, Weeping fig tree, Ficus benjamina $(6.55 \mathrm{~m})$, Rain tree, Samanea saman $(5.73 \mathrm{~m})$, Blackboard tree, Alstonia sholaris $(5.67 \mathrm{~m})$, Moluccan albizia tree, Albizia falcafacia $(4.20 \mathrm{~m})$ and Fern tree, Filicium decipiens $(2.40 \mathrm{~m})$. Perch observation for artificial structure was only at the height of $0.8 \mathrm{~m}$ on a public parking signage (Table 3 ).
Out of 59 song perch observations containing songs and calls (66.29\%), 32 clear vocal outputs $(54.23 \%)$ were used directly as sample size without filtering background noise. Songs produced by the Pied Triller were higher in terms of minF, domF, amp, duration of vocal and the number of syllables compared to the three call types. Call type $\mathrm{C}$ has the highest maxF compared to the other vocal type. The six parameters analysed for each vocal outputs are summarised in Table 4.

Table 3. Perch height and perch object description

\begin{tabular}{lccc}
\hline Perch object & Range height $(\mathrm{m})$ & Average perch height $(\mathrm{m})$ & Optimum perch height $(\mathrm{m})$ \\
\hline Acacia tree & $4.20-12.50$ & $7.56 \pm 3.19$ & $12.56 \pm 4.54$ \\
Moluccan albizia tree & $3.80-4.40$ & $4.20 \pm 0.28$ & 7.40 \\
Blackboard tree & $2.80-7.20$ & $5.67 \pm 1.38$ & $7.65 \pm 0.59$ \\
Weeping fig tree & $3.20-13.80$ & $6.55 \pm 2.21$ & $10.76 \pm 2.19$ \\
Fern tree & 2.40 & 2.40 & 4.40 \\
Cheese tree & $2.40-11.40$ & $8.13 \pm 4.07$ & $11.53 \pm 3.19$ \\
Weeping paperbark tree & 21.60 & 21.60 & 22.60 \\
Rain tree & $4.00-6.60$ & $5.73 \pm 1.12$ & $10.07 \pm 0.10$ \\
Public parking signage & 0.80 & 0.80 & 0.80 \\
\hline
\end{tabular}

Table 4. Average values of vocal parameters for four vocal types

\begin{tabular}{lcccccc}
\hline & MinF $(\mathrm{kHz})$ & MaxF $(\mathrm{kHz})$ & DomF $(\mathrm{kHz})$ & $\begin{array}{c}\text { Amp } \\
(\mathrm{dB})\end{array}$ & $\begin{array}{c}\text { Duration } \\
(\mathrm{s})\end{array}$ & $\begin{array}{c}\text { Number of } \\
\text { syllables }(\mathrm{n})\end{array}$ \\
\hline Song type & $1533.48 \pm$ & $4738.17 \pm$ & 3134.61 & 33.33 & 2.27 & 14.30 \\
& 92.55 & 186.47 & \pm 164.01 & \pm 40.56 & \pm 0.69 & \pm 4.49 \\
Call type A & $1397.88 \pm$ & $4844.00 \pm$ & $2863.88 \pm$ & 3.64 & 0.43 & 2.50 \\
& 300.89 & 280.23 & 605.63 & \pm 1.01 & \pm 0.29 & \pm 0.87 \\
Call type B & - & - & - & - & - & - \\
Call type C & 1317.00 & 5240.00 & 2842.00 & 5.46 & 0.07 & 1.00 \\
\hline
\end{tabular}

Notes: (-) indicates vocal analysis was not available 


\section{The Relationship Between Perch Height and Vocalisation}

The following test shows the relationship between perch height with song type and call type A. Call type $B$ and $C$ was not further analysed because the vocal output recorded for call type B was of poorer quality while the number of recordings for call type $\mathrm{C}$ was insufficient to be considered a minimum sample size.
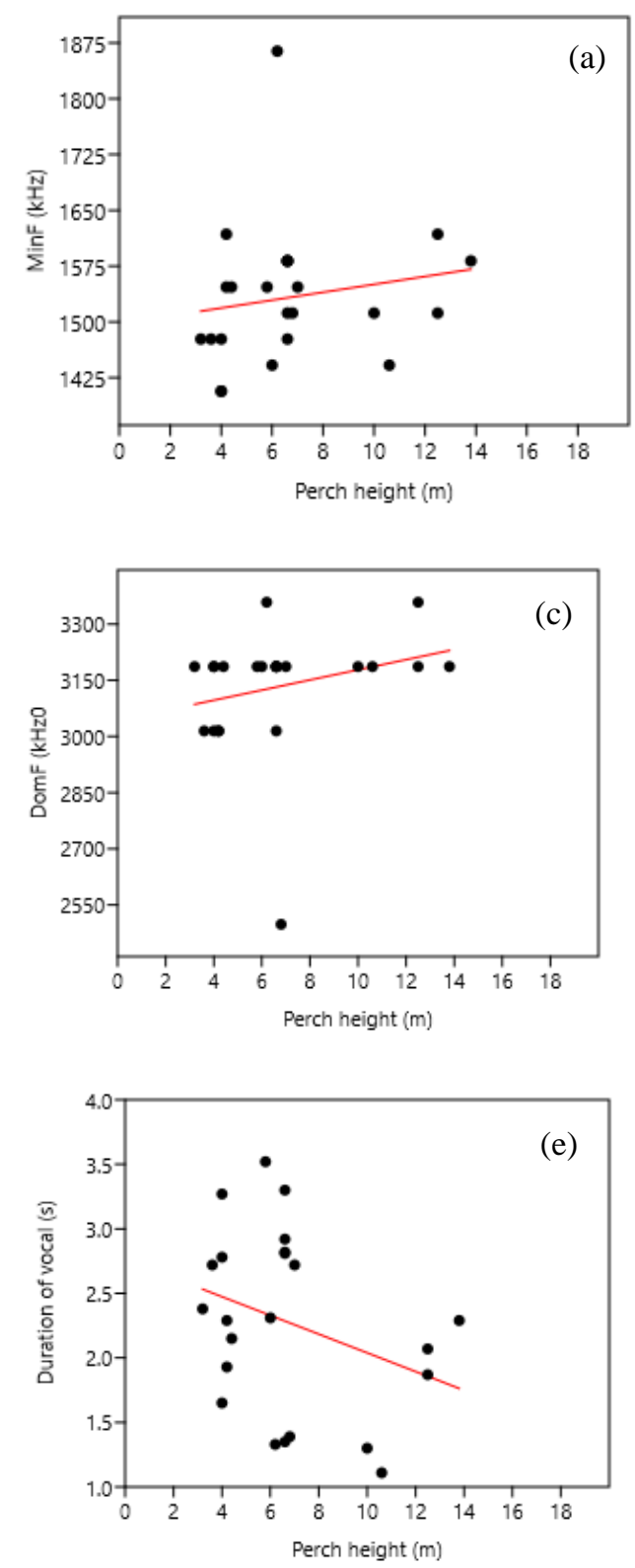

Song type - All parameters show low negative correlation against perch height ((b): maxF: $r=-$ 0.16 ; (d): amp: $r=-0.20$; (e): duration: $r=-0.32$; (f): number of syllables: $r=-0.21)$ ) except $\operatorname{minF}$ and domF where they show low positive correlation toward perch height ((a): minF: $\mathrm{r}=$ 0.17; (c): domF: $r=0.25$ ) (Figure 5).
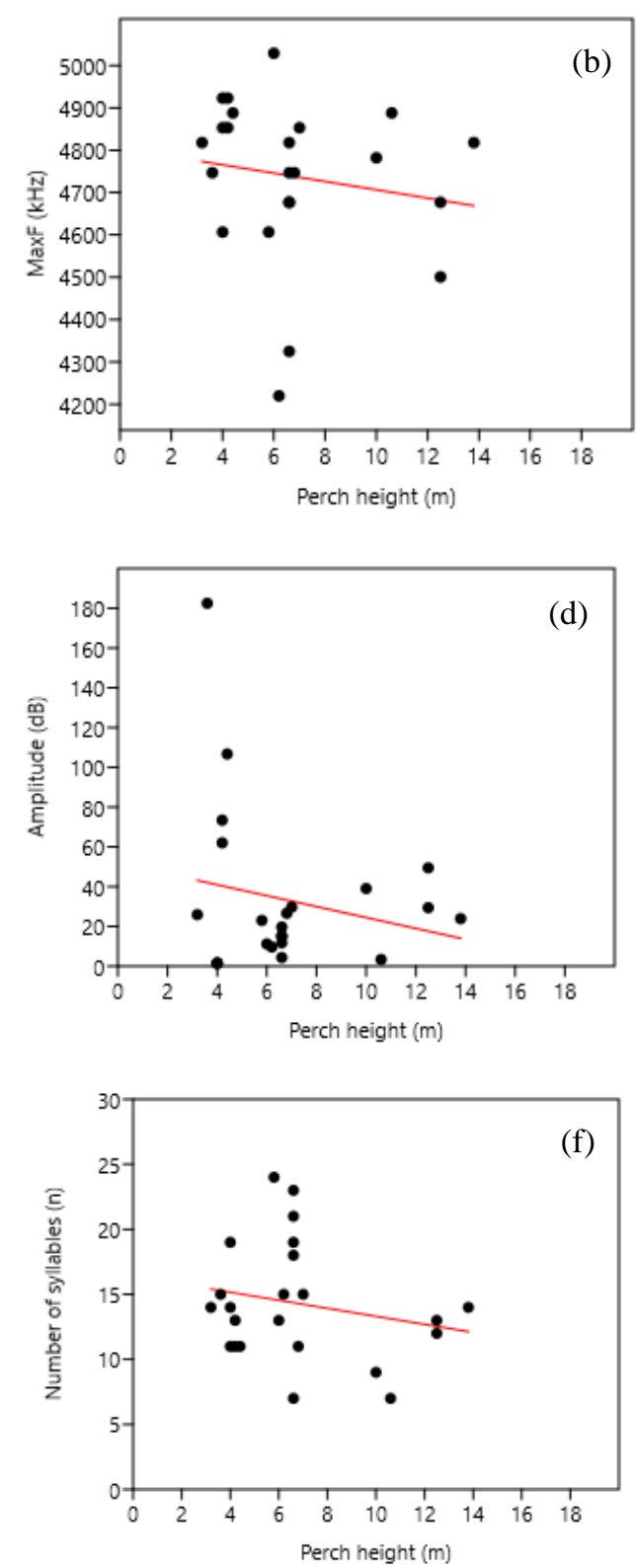

Figure 5. Relation between (a) $\operatorname{minF}$, (b) $\operatorname{maxF}$, (c) domF, (d) amp, (e) duration of vocal and (f) number of syllables of song type towards perch height 
Call type A - All parameters show low positive correlation against perch height ((a): minF: $\mathrm{r}=$ 0.45 ; (b): $\operatorname{maxF}: r=0.31$; (c): domF: $r=0.05$; (d): amp: $r=0.37$; (f): number of syllables: $r=0.16$ )) except duration of vocal as it shows low negative correlation toward perch height ((e): duration: $r=$ 0.26) (Figure 6).

\section{DISCUSSION}

Pied Triller was observed to have preference to perch on tree structures $(97.75 \%)$ compared to artificial structures (2.25\%). Passerine birds such as Pied Triller have anisodactyl foot (Proctor \&
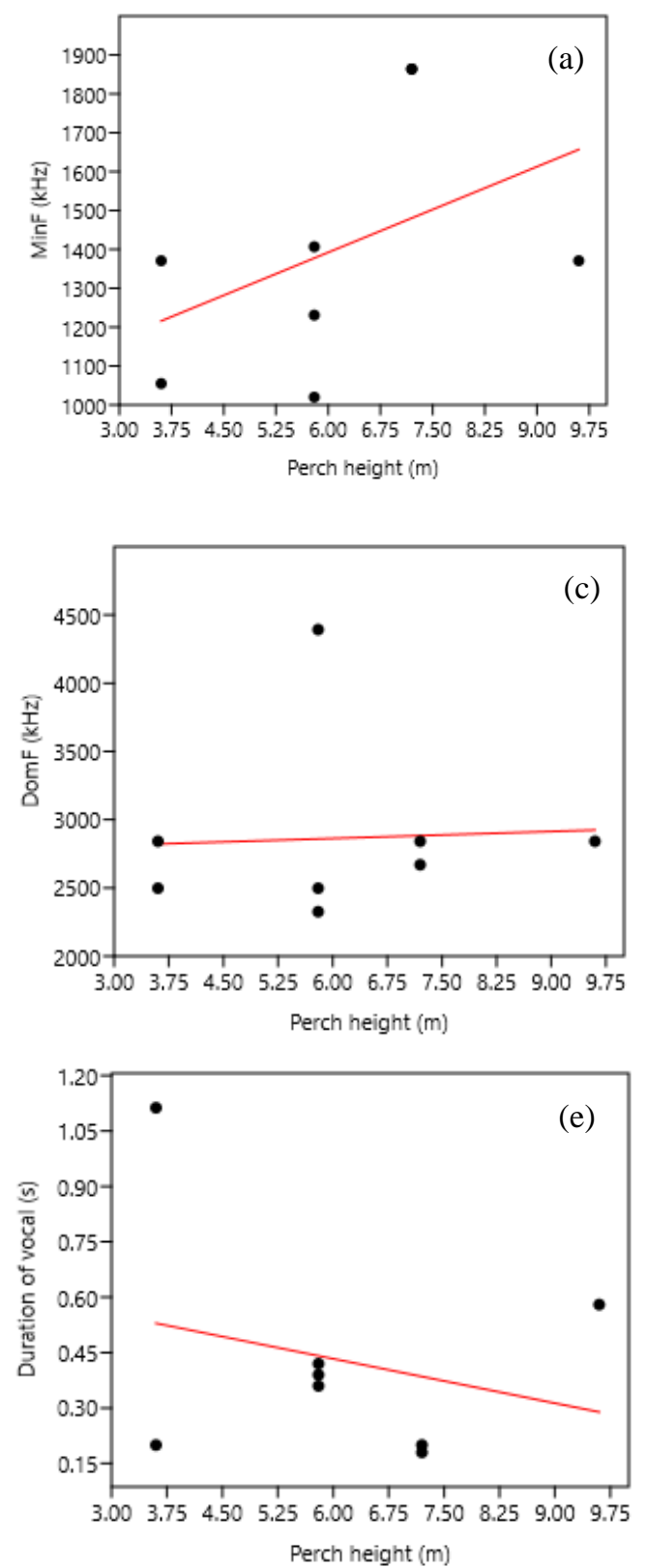

Lynch, 1993) evolved to best fit around tree branches (Mench \& Blatchford, 2014), stems or twigs as their toe segments are the right lengths to allow their toes to bend comfortably around them (Welty \& Baptista, 1988). This suggests the reason for such preference for tree perch as they have better grip on natural structures. The public parking signage is made of metal therefore it is more difficult to perch on. They were also observed among foliage of medium trees such as Cheese tree, Fern tree and Weeping fig tree, and on large trees such as Acacia tree, Blackboard tree, Moluccan albizia tree, Rain tree and Weeping paperbark tree. Weeping fig tree, Ficus benjamina was the most
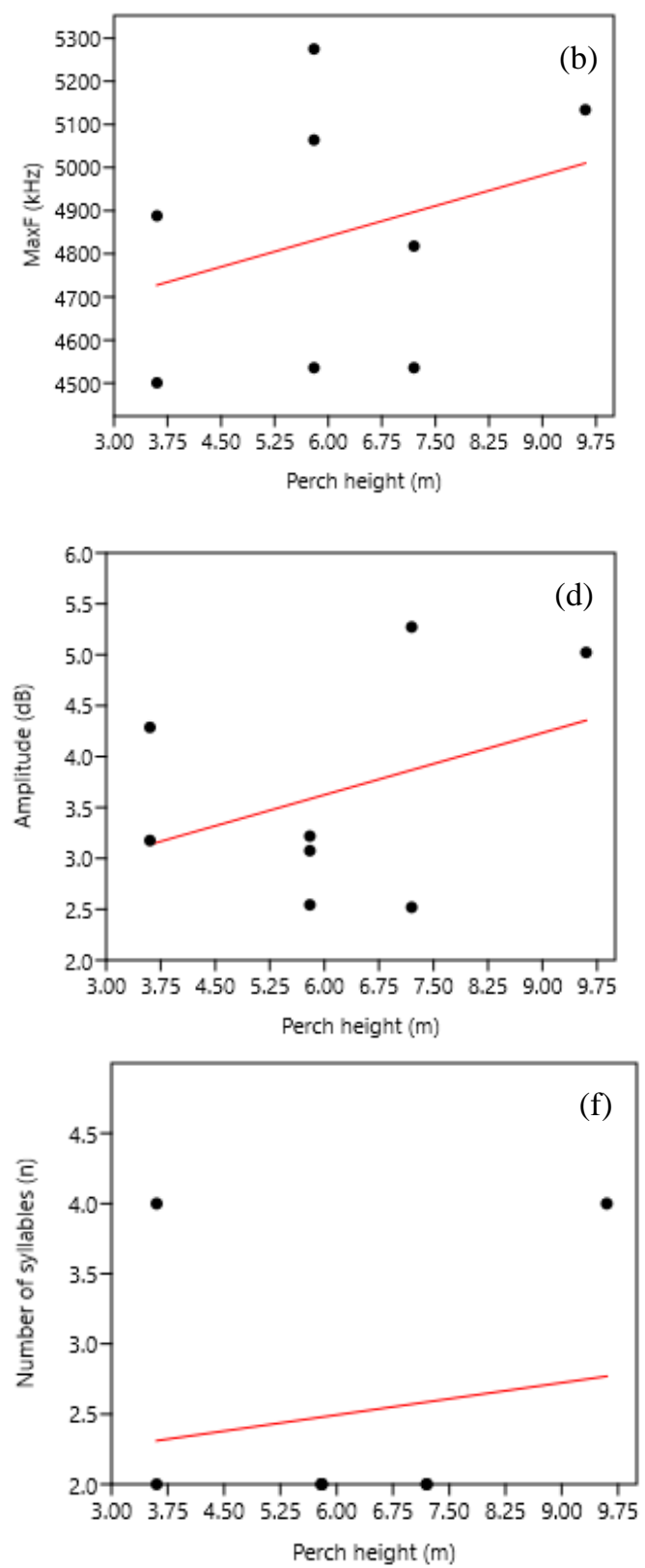

Figure 6. Relation between (a) $\operatorname{minF}$, (b) $\operatorname{maxF}$, (c) domF, (d) amp, (e) duration of vocal and (f) number of syllables of call type A towards perch height 
frequent tree perch by Pied Triller. Possible reason why Pied Trillers prefer this tree species compared to the other fruiting tree species to forage for insects (Phillipps \& Phillipps, 2014) maybe due to the availability of Fig wasps, Eupristina koningsbergeri the pollinators of the Weeping fig tree (Zhang \& Yang, 2017).

The most observed behaviour by the Pied Triller was perch-hop $(33.71 \%)$ while flight behaviour was the least observed behaviour display (1.12\%). Perch-hop is described as the bird moving from one place to another by propelling itself continuously with its feet (Smith \& Wassmer, 2016) with occasional short flights to the nearest branch in between. Small and light garden bird prefers to hop rather than running or flying as it is the quickest and most effective way to get about in a tree (Welty $\&$ Baptista, 1988). Flight requires the bird to flap therefore it is energetically more costly than running (Butler, 2016) and hopping. Perchhopping may also be the best locomotion for tradeoff between energy costs and gains when foraging (Scott, 2005). Pied Trillers were often observed perch-hopping from branch to branch among the foliage with occasional short flights to the nearest branch and pausing in between to emit songs and calls.

Based on perch height selection, song type shows a negative correlation for all parameters except minF and domF. This may suggest that song type is not necessarily used for communication between individuals of the species as the perch height increases. Song type may function significantly for male Pied Trillers to defend their territory and to attract females (Catchpole \& Slater, 2008). Songs with higher minimum and dominant frequency are more favourable as they help to project the song louder and further away (Luther \& Baptista, 2010; Magalhães Tolentino et al., 2018). Furthermore, emitting songs tend to make the bird to be more conspicuous (Beck \& George, 2000) as the duration of vocal output is longer compared to calls. Therefore, emitting songs increases the probability of predation by cats (Møller, 2011) or raptors (Beck \& George, 2000).

Call type A in this study however shows a positive correlation for all parameters except duration of vocal output. Calls emitted by the bird tend to increase in minF, maxF, domF, amp and number of syllables with the increase in perch height as to improve interactions with conspecifics (Beck \& George, 2000).

Another factor that may influence the perch height selection on vocalisation is due to urbanisation. Birds exposed to urbanisation for a long time tend to sing at higher position in the vegetation (Møller, 2011). Since anthropogenic noise in urban areas is noisy and has higher minimum frequency (Hu \& Cardoso, 2009), birds of an open habitat tend to have higher pitch songs (Welty \& Baptista, 1988) with higher sound level and higher low frequencies (Møller, 2011). Birds will try to mitigate communication impairments that masks their songs with the background noise to maintain song output distance in territory defense and mate attraction (Brumm, 2004). Birds often incorporate regular rhythms such as trills and pure sounds such as whistles to make the sound more out stand from the background (Catchpole \& Slater, 2008). Pied Triller emits a distinctive nasal sound as a technique to unmask their vocal output by the background noise of urban surrounding.

\section{CONCLUSION}

Pied Triller produced song output with lower maximum frequency, amplitude, duration and number of syllables but higher minimum and dominant frequency. This vocalisation strategy could probably benefit the species to remain inconspicuous from potential predators like raptors and cats while maintaining song distance. In contrast, call output has higher minimum frequency, maximum frequency, dominant frequency, amplitude and number of syllables as perch height increases to improve interactions with conspecifics. The preference of high perch height when calling over singing probably suggested that Pied Triller prioritised vocal transmission and call sign. This garden bird species preferred tree structures to perch over artificial structures due to their anisodactyl foot ideal for perching on trees. The most frequently visited perch object was the Weeping fig tree, Ficus benjamina. 


\section{ACKNOWLEDGEMENTS}

We would like to thank Pustaka Negeri Sarawak for granting us access and permission to conduct the study within the recreational park area (Ref No. (047)PUSTAKA/800-1/2/JLD.9). This project was supported by grant F07/SpMyRA/1710/2018 awarded to MFSR. We also thank friends and colleagues in the Faculty of Resource Science and Technology, UNIMAS for assisting in data collection, especially to Mr. Isa Bin Sait, Mr. Mohamad Jalani Bin Mortada and Ms. Rahah Binti Mohamad Yakup.

\section{REFERENCES}

Barker, N.K.S. \& Mennill, D.J. (2009). Song perch height in rufous-and-white wrens: Does behaviour enhance effective communication in a tropical forest? Ethology, 115(9): 897-904.

Beck, M.J. \& George, T.L. (2000). Song post and foraging site characteristics of breeding Varied Thrushes in Northwestern California. The Condor, 102(1): 93-103.

Bibby, C., Burgess, N. \& Hill, D. (1992). Bird census techniques. London, UK: Academic Press Limited.

Brumm, H. (2004). The impact of environmental noise on song amplitude in a territorial bird. Journal of Animal Ecology, 73(3): 434-440.

Butler, P.J. (2016). The physiological basis of bird flight. Philosophical Transactions of the Royal Society of London. Series B: Biological Sciences, 371(1704): 20150384.

Catchpole, C.K. \& Slater, P.J.B. (2008). Bird song: Biological themes and variations. Second Edition. Cambridge, UK: Cambridge University Press.

Hammer, Ø., Harper, D.A.T. \& Ryan, P.D. (2001). PAST: Paleontological Statistics Software Package for Education and Data Analysis. Palaeontologia Electronica, 4(1): 1-9.

Hu, Y. \& Cardoso, G.C. (2009). Are bird species that vocalize at higher frequencies preadapted to inhabit noisy urban areas? Behavioral Ecology, 20(6): 1268-1273.

Krams, I. (2001). Perch selection by singing chaffinches: A better view of surroundings and the risk of predation. Behavioral Ecology, 12(3): 295300 .
Luther, D. \& Baptista, L. (2010). Urban noise and the cultural evolution of bird songs. Proceedings of the Royal Society B: Biological Sciences, 277: 469-473.

MacKinnon, J. \& Phillipps, K. (1993). A field guide to the birds of Borneo, Sumatra, Java and Bali. New York, USA: Oxford University Press.

Magalhães Tolentino, V.C., Baesse, C.Q. \& Melo, C. (2018). Dominant frequency of songs in tropical bird species is higher in sites with high noise pollution. Environmental Pollution, 235: 983-992.

Mench, J.A. \& Blatchford, R.A. (2014). Laboratory animal welfare. California, USA: University of California.

Møller, A.P. (2011). Song post height in relation to predator diversity and urbanisation. Ethology, 117(6): 529-538.

Pharo, A.H., Saiee, D. \& Mahmud, Y. (2015). Alam Pustaka: The world of Pustaka. Kuching, Sarawak: Pustaka Negeri Sarawak.

Phillipps, Q. \& Phillipps, K. (2014). Phillipps' field guide to the birds of Borneo: Sabah, Sarawak, Brunei and Kalimantan. Third Edition. New Jersey, USA: Princeton University Press.

Proctor, N.S. \& Lynch, P.J. (1993). Manual of ornithology: Avian structure and function. London, UK: Yale University Press.

Scott, G. (2005). Essential animal behavior. Oxford, UK: Blackwell Publishing Ltd.

Smith, O. \& Wassmer, T. (2016). An ethogram of commonly observed behaviors of the endangered Bridled White-eye (Zosterops conspicillatus) in a zoo setting. The Wilson Journal of Ornithology, 128(3): 647-653.

Smythies, B.E. (1999). The birds of Borneo. Fourth Edition. Kota Kinabalu, Sabah: Natural History Publications (Borneo).

Stanton, L.A. (2016). A standardized ethogram for the Felidae: user guide. http://animalcognitionlab.org/ sites/default/files/Stanton_Guidelines_for_Ethogra m2015.pdf

Voon, A.M.F., Ku Nasradhi, K.N.A, Rahman, M.A. \& Mohd Azlan, J. (2014). Bird diversity, density and foraging activities in a university campus landscape in Sarawak. Borneo Journal of Resource Science and Technology, 4(2): 9-20.

Vowles, G.A. \& Vowles, R.S (eds). (1997). An annotated checklist of the birds of Brunei. Gloucestershire, England: Centro de Estudos Ornitológicos no Algarve. 
Welty, J.C. \& Baptista, L. (1988). The life of birds. Fourth Edition. Orlando, Florida: Saunders College Publishing.

Xeno-Canto Foundation (2013). Pied Triller, Lalage nigra. Retrieved October 15, 2018, from https://www.xeno-canto.org/species/Lalagenigra
Zhang, X. \& Yang, D. (2017). Occurrence of internally ovipositing non-agaonid wasps and pollination mode of the associated agaonid wasps. Plant Diversity, 39(3): 130-134.

Zainudin, S.R., Mustafa, K.A., Austin, D., Helmy, J. \& Lingkeu, D.A. (2012). Urban trees diversity in Kuching North City and UNIMAS, Kota Samarahan, Sarawak. Journal of Tropical Agricultural Science, 35(1): 27-32. 